\title{
Web-Based Tools for Teaching Dendrochronology
}

\author{
Paul R. Sheppard*
}

\begin{abstract}
This article describes two web-based tools for teaching dendrochronology, the scientific study of tree rings, and presents quantitative evaluations of their value in a large class. Because of its wide scientific applicability, dendrochronology is appropriate for teaching in a wide array of courses, including those in the fields of natural resources and life sciences. Until recently, professors have not had quick and efficient ways to teach basic tenets of tree-ring analysis, including crossdating. One strategy is to apply technological tools, especially the World Wide Web, to teaching topics such as dendrochronology generally and crossdating specifically. To fill this need, I developed a Java-language applet simulation for teaching crossdating by skeleton plotting. I also compiled a web-based module on forest fire management in the Southwest, a real and current environmental issue that incorporates dendrochronology. To evaluate the effectiveness of these web-based teaching tools, they were used in a large course and the students were then surveyed and tested with multiplechoice and true-false questions covering the topics of crossdating and forest fire management. The crossdating applet package resulted in substantial comprehension of what was a new concept for most of the students. The southwestern forest fire management module also resulted in significant improvement in understanding of that complex environmental issue. I welcome other educators to use these web-based tools, currently available here: http://www.Itrr.arizona.edu/skeletonplot/introcrossdate.htm (verified 10 Oct. 2002) and http://www.Itrr.arizona.edu/ $\sim$ sheppard/swland/swfire.html (verified 10 Oct. 2002).
\end{abstract}

$\mathrm{T}$ WO WEB-BASED TOOLS for teaching dendrochronology were recently developed and then implemented and evaluated at the college level. This article describes these tools in detail and presents quantitative evaluation of their value in class. Dendrochronology, the scientific study of tree rings, has been applied in many fields of research, including climatology (Fritts, 1991), geology (Jacoby et al., 1988), ecology (Fritts and Swetnam, 1989), environmental sciences (Lewis, 1995), archaeology (Dean, 1969), and even forensics (Jozsa, 1985). Because of its wide applicability, dendrochronology is appropriate for teaching in a wide array of courses, including in the fields of natural resources and life sciences.

Until recently, professors who might have included at least a unit on dendrochronology in their courses have not had quick and efficient ways to teach basic tenets of tree-ring analysis. Teaching crossdating, for example, has required microscopes, various lab supplies, and actual wood specimens. One alternative to this is applying technological tools, especially the World Wide Web, to instruction (Young, 1998). Incorporating the web into instruction enhances student learning in the following ways (Czerniak et al., 1999):

Laboratory of Tree-Ring Research, University of Arizona, Tucson, Arizona 85721. Received 13 Mar. 2002.*Corresponding author (sheppard@1trr.arizona.edu).

Published in J. Nat. Resour. Life Sci. Educ. 31:123-130 (2002) http://www.JNRLSE.org
- Web-based instruction promotes active rather than passive learning (Carr-Chellman and Duchastel, 2000).

- Web-based modules allow for continuous evaluation and quick modification (Whittingham and Campbell, 1999).

- Web-based material is available to students all the time, unlike libraries or instructors (Carr-Chellman and Duchastel, 2000), and students can work on their own schedule and at their own speed (Pelton and Pelton, 1998).

- Computer-based teaching helps students gain both knowledge (i.e., information that can be recalled) and understanding (i.e., the capacity to apply concepts to real and pertinent situations) (Hill et al., 1998).

\section{WEB-BASED TEACHING TOOLS}

\section{Crossdating Applet Package}

\section{(http://www.ltrr.arizona.edu/skeletonplot/} introcrossdate.htm; verified 10 Oct. 2002)

For teaching crossdating by skeleton plotting, I wrote a Java-language applet simulation program with the goal that it be as realistic as possible. Simulation is a particularly good use of computer-based teaching (Hill et al., 1998; Scherly et al., 2000). Each time the applet is executed, a new virtual treering increment core sample is created using random numbers. The core sample has two-tone rings, simulating the light-colored earlywood and dark-colored latewood that is typical of annual rings of conifers (Fig. 1). The default setting is for six decades of rings, which is enough to crossdate samples confidently. Every 10th ring is automatically dotted and numbered to aid in correctly counting the rings.

Typical samples are too long to be seen in their entirety on computer screens, but the sample can be dragged left and right with the mouse, allowing the user to see all rings. The view of the rings can be magnified with buttons that zoom the image in or out, allowing confirmation of very narrow rings at high magnification or a larger field of view at low magnification. This reflects reality in that crossdaters constantly change the magnification of their microscopes to accommodate wide and narrow rings.

The engineering graph paper typically used in real skeleton plotting is simulated in the applet (Fig. 1). As with the core sample, the graph paper can be dragged left and right and the view of the graph paper can be enlarged or reduced.

The core sample is skeleton plotted by making marks on the graph paper to represent distinctive rings (Fig. 1). For example, vertical marks are made on graph lines representing particularly narrow rings - the narrower the ring, the longer the mark. With the applet, the user puts the cursor over the corresponding graph line at the desired height and clicks once to make a mark. If a mistake is made, it can be removed by switching the cursor to an erase mode. For exceptionally wide rings, a small-case $b$, indicating big ring, can be added to the skeleton plot. A few $b$ marks help confirm crossdating, but the important marks for crossdating are those representing narrow rings. A key point is that not all rings are marked, as most rings are average and therefore do not merit any mark on a skeleton plot. 
After skeleton plotting the sample, a dated master chronology, which is a time series of dimensionless index values, is used for finding the year dates of the sample (Fig. 1). The master chronology is six times longer than the sample, and the sample crossdates somewhere within the master. The master chronology can be dragged left and right and is also resizable.

To find the crossdated position of the sample, the master is dragged left and right until the mirror image pattern of vertical marks in the skeleton plot is found within the master (Fig. 1). No other portion of the master will match the skeleton plot as well as the correct position. Once the correct position is found, the core start date is the master chronology year corresponding with the first line of the skeleton plot, and the core end date is the master chronology year corresponding with the last line of the skeleton plot. These dates are checked by clicking the Answer button to alternately show or hide an answer panel (Fig. 1).

The default settings of the applet generate a sample that is reasonably easy for beginners to succeed at crossdating. Three settings can be changed to make more difficult crossdating problems - sensitivity, number of rings in the sample, and potential occurrence of ring-growth anomalies. One, sensitivity, defaults to high sensitivity, which is high year-to-year variability (Fritts, 1976). This can be changed to complacent, which is little year-to-year variability. As interannual variability diminishes, there are fewer distinctive rings to skeleton plot, making it more difficult to find a match with the master chronology.

Two, the number of rings in the sample can be changed. Regardless of its sensitivity, a short sample has little opportunity to display a distinctive pattern of ring widths and is therefore difficult to crossdate. As sample length increases, the chances of successfully crossdating improve. It is especially important to have more rings available when crossdating a complacent sample.

Three, the potential occurrence of ring-growth anomalies can be turned on. Missing rings are when a tree simply did not grow a ring for a year due to unfavorable environmental conditions such as a drought (Fritts, 1976). False rings are when a tree grew two rings during a year due to environmental conditions favoring ring growth during two periods of the growing season separated by an unfavorable period (Leavitt et al., 1998). In the default setting, missing and false rings are not drawn in the sample. Clicking on these ring anomalies means only that they might occur in the sample, not that they will occur. A Hint button shows whether or not ring anomalies have occurred in a sample, and if so, then the Answer button includes their dates.

The crossdating tool also includes a suite of 11 web pages that define, describe, and explain crossdating by skeleton plotting. Some pages have smaller applets to prepare users for the crossdating applet. These pages are presented in order by using Next and Previous links so they can be viewed sequentially. They also have links to all other pages in the package so they can be viewed in any order while going back and forth to the applet.

\section{Southwest Forest Fire Management Module (http://www.ltrr.arizona.edu/ sheppard/swland/swfire. html; verified 10 Oct. 2002)}

With the crossdating applet package completed, I compiled a web-based module of materials pertinent to the environmental issue of forest fire management in the Southwest. This

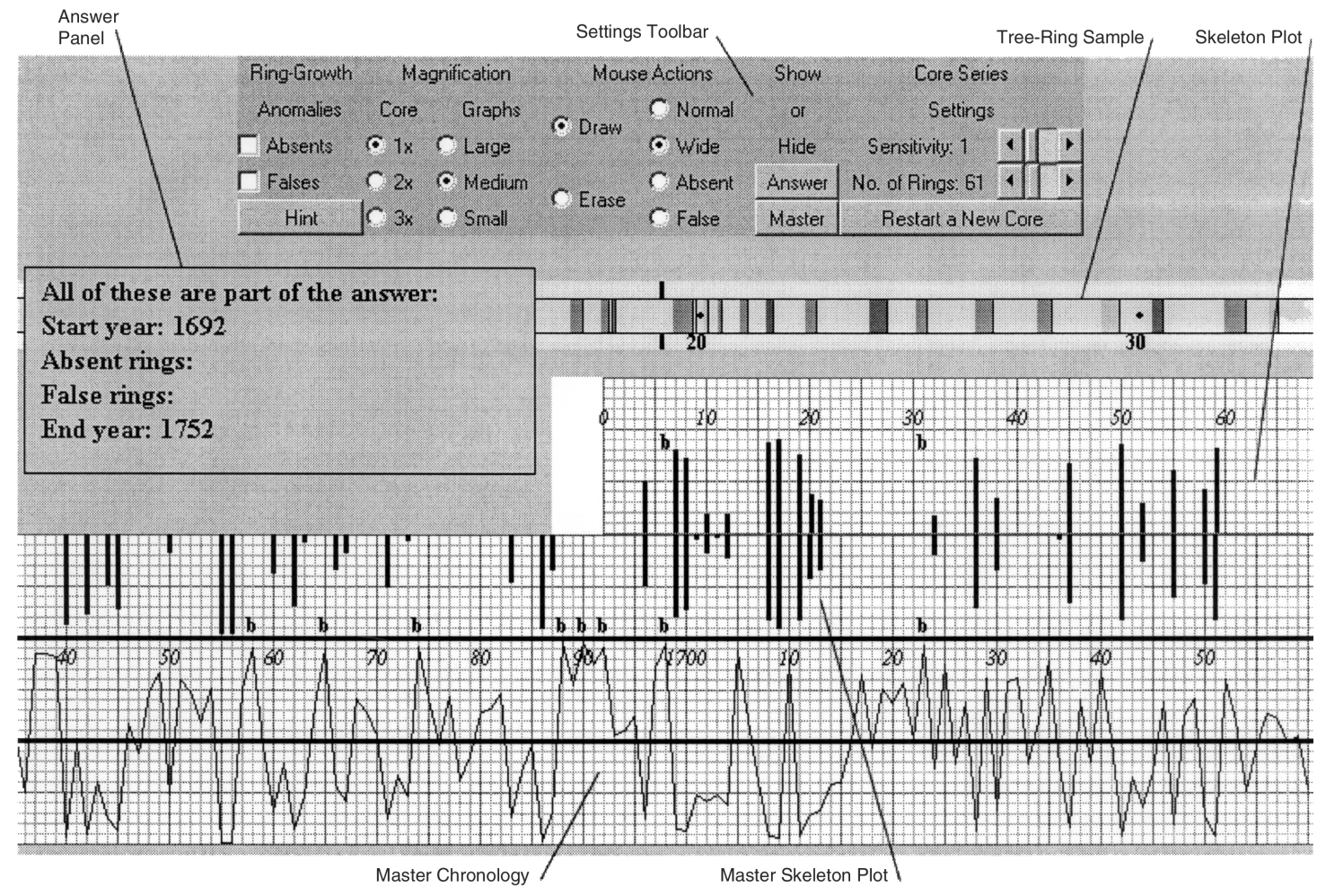

Fig. 1. Web-based crossdating applet. The rings of the core sample and the time scale of the graphs both progress from left to right. The tree-ring sample, skeleton plot, and master chronology and its skeleton plot can all be moved horizontally. 
issue is excellent for student writing assignments because of its realism and complexity (Surry and Land, 2000). Forest fires are major news items and dendrochronological crossdating shows that fire patterns of the past were quite different from patterns of today (Swetnam and Baisan, 1996). This comparison allows discussion of how and why fire patterns have changed through time. Management options exist for restoring wildland fire to some prehistoric condition and thereby reducing the hazards of modern wildfires (Babbitt, 1995), but each option has disadvantages along with advantages. Thus, with forest fire management, students grapple with a real and current environmental issue that has no easy solutions and that incorporates dendrochronology and crossdating.

The design goal for the forest fire management module was to provide ample and varied information on many facets of the issue (Hill et al., 1998). Various web pages introduce the topic, give examples of recent big fires and their environmental impacts, discuss prehistoric fire patterns and how they were determined (including a direct link to the crossdating applet), and compare and contrast management options. HTML newspaper clippings, PDF-format scientific articles (with passwords to limit access to students), and data figures such as dendrochronologically developed master fire chronologies from all over the Southwest (Fig. 2) are provided. The master fire chronologies are primarily from ponderosa pine (Pinus ponderosa Dougl. ex Laws.) forests, which typically have abundant fire-scarred trees from which to dendrochronologically reconstruct fire regimes (Grissino-Mayer and Swetnam, 1997). More information is provided in the module than can reasonably be included in a student essay, which forces students to choose what to cover and what to ignore (Collis, 1998). A detailed essay assignment is provided so that students have guidance when they are exploring through the ample information (Hill et al., 1998).

A ramification of this web-based module is that students do not need to locate content material on their own, a learning skill that remains as important now as ever before (Farber, 1999). This can be considered a drawback. However, asking students to locate material on a complex environmental issue could potentially render this assignment impossible; students could devote most of their time to just finding and judging the pertinence of primary sources. While students do not get to practice their library research skills when material is simply handed to them on a web-based module, they can focus their thinking and writing efforts on the environmental issue without the burden of finding material.

\section{METHODS OF EVALUATION}

Since creating the crossdating applet package and the Southwest forest fire management module, these web-based tools have been used in various courses. Although experiential and anecdotal evidence exists to judge their effectiveness, I evaluated both teaching tools more formally during the fall 2001 semester of the Environmental History of the Southwest course at the University of Arizona. This course exposes lower-division, nonscience majors to scientific concepts and the use of scientific techniques in the study of human-environment interactions (University of Arizona, 2002). The course has a writing component whereby students write 1000word essays on complex issues and shorter summaries of technical issues. The instruction is pitched to the level of sophomores, the dominant student class taking the course (official registration data for the fall 2001 semester).

Students did the skeleton plotting package early in the semester to instill appreciation of dendrochronological data discussed in subsequent lectures. A couple of brief, in-class demonstrations of the applet were provided before students tried it for themselves. The assignment was to try at least one crossdating exercise with the default settings, paste a screen image of the completed crossdating session into a text document to prove that an exercise had been done, and fill in the page with a short essay on crossdating based on that experience and on the explanatory pages, for example, applications, strengths, and limitations of crossdating.

After completing the crossdating assignment, students were surveyed and tested to assess how well they learned crossdating and how they used the applet. The survey included questions on student backgrounds as well as how they executed the applet and interacted with the entire package. The survey was composed of yes-no or multiple-choice questions along with two open-ended questions, and the test had multiple-choice and true-false questions (Suskie, 1996). One-way analyses of variance (Sokal and Rohlf, 1981) of test scores for student groups, based on the survey results, were the basis for evaluating the applet package.

Later in the semester, students completed the Southwest forest fire management module and essay. After hearing a lecture on forest fire management in the Southwest and an inclass introduction to the web-based module on Southwest fire management, students negotiated the module on their own time. Essays were required to include an introduction to the issue, at least one data figure, arguments for and against a chosen management option, and literature citations.

To evaluate the effectiveness of the Southwest fire management module, students were tested twice with multiplechoice and true-false questions covering concepts of this issue. The test was administered before the students used the module and wrote their essays and then again after the essay assignment was completed, which was 4 wk later. A direct

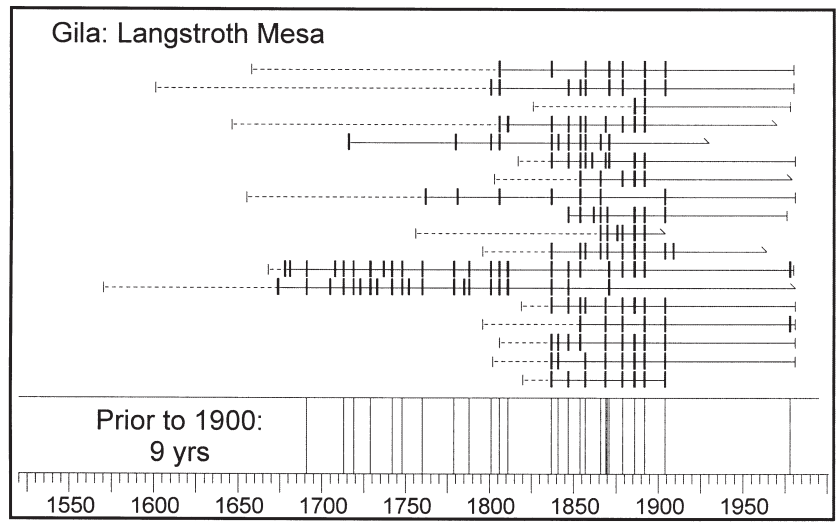

Fig. 2. Dendrochronological master fire chronology from Langstroth Mesa, in the Gila Mountains, New Mexico. Horizontal lines represent the life spans of individual trees, with dashed portions indicating years before a tree's first fire scar. Vertical tick marks represent crossdated abrasion scars left on the trees by past fires. The composite at the bottom is a summary of all sampled trees at this site, and it shows an average return interval for low-intensity ground fires of about $9 \mathrm{yr}$ before 1900 . Since 1900, these trees have recorded only one low-intensity ground fire. 
comparison of pretest and posttest performance was the basis for evaluating the effectiveness of the module.

In both evaluations, students were surveyed or tested in regular class sessions, and only students who attended those classes and voluntarily participated in the evaluations were included as research subjects. All surveys and tests were done anonymously. Each survey or test needed less than $15 \mathrm{~min}$ to complete and thus respondent fatigue was avoided (Shaw and Marlow, 1999).

Table 1. Questions and results for crossdating survey.

\begin{tabular}{|c|c|c|c|c|}
\hline Question & Answer & $\begin{array}{l}\% \text { of } \\
\text { Respond- } \\
\text { ents }\end{array}$ & $\begin{array}{l}\% \text { Test } \\
\text { score (SE } \\
\text { of mean) }\end{array}$ & $\begin{array}{c}P \\
\text { value }\end{array}$ \\
\hline \multirow[t]{8}{*}{ 1. Year in college? } & Freshman & 3 & $64(11.0)$ & \multirow[t]{4}{*}{0.14} \\
\hline & Sophomore & 33 & 70 (2.9) & \\
\hline & Junior & 42 & $67(2.1)$ & \\
\hline & Senior & 22 & $76(2.9)$ & \\
\hline & Lower classmen & 36 & $69(2.8)$ & \multirow[t]{2}{*}{0.72} \\
\hline & Upper classmen & 64 & $70(1.8)$ & \\
\hline & Below senior & 78 & $68(1.7)$ & \multirow[t]{2}{*}{0.03} \\
\hline & Senior or above & 22 & $76(2.8)$ & \\
\hline \multirow[t]{2}{*}{ 2. Major? } & Science & 11 & $74(3.8)$ & \multirow[t]{2}{*}{0.40} \\
\hline & Nonscience & 89 & $70(1.6)$ & \\
\hline \multirow{5}{*}{$\begin{array}{l}\text { 3. Familiar with skeleton } \\
\text { plotting? }\end{array}$} & Not at all & 92 & $70(1.6)$ & \multirow[t]{3}{*}{0.80} \\
\hline & Somewhat & 7 & $74(5.5)$ & \\
\hline & Very & 1 & $71(\varnothing)$ & \\
\hline & Not at all & 92 & $70(1.6)$ & \multirow[t]{2}{*}{0.51} \\
\hline & At least somewhat & 8 & $73(4.7)$ & \\
\hline \multirow{2}{*}{$\begin{array}{l}\text { 4. Experience with computer } \\
\text { activities? }\end{array}$} & Yes & 32 & $72(1.9)$ & \multirow[t]{2}{*}{0.31} \\
\hline & No & 68 & $69(2.5)$ & \\
\hline \multirow[t]{2}{*}{ 5. Change size of graph paper? } & Yes & 50 & $70(2.4)$ & \multirow[t]{2}{*}{0.75} \\
\hline & No & 50 & $70(1.9)$ & \\
\hline \multirow{2}{*}{$\begin{array}{l}\text { 6. Change size of tree-ring } \\
\text { sample? }\end{array}$} & Yes & 65 & $70(2.0)$ & \multirow[t]{2}{*}{0.89} \\
\hline & No & 35 & $70(2.3)$ & \\
\hline \multirow[t]{2}{*}{ 7. Erase marks on plot? } & Yes & 85 & $70(1.7)$ & \multirow[t]{2}{*}{0.85} \\
\hline & No & 15 & $69(3.6)$ & \\
\hline 8. Easy to move sample or & Very easy & 56 & $74(1.8)$ & 0.006 \\
\hline graph papers? & Fairly easy & 31 & $68(2.8)$ & \\
\hline & Somewhat difficult & 12 & $58(4.0)$ & \\
\hline & Very difficult & 1 & $57(\varnothing)$ & \\
\hline & Easy & 86 & $72(1.6)$ & 0.002 \\
\hline & Difficult & 14 & $58(3.6)$ & \\
\hline 9. Time plotting, matching & $<10 \min$ & 33 & $74(2.2)$ & 0.17 \\
\hline with master? & $10-20 \mathrm{~min}$ & 32 & $70(3.1)$ & \\
\hline & $20-40 \mathrm{~min}$ & 20 & $66(3.7)$ & \\
\hline & $>40 \mathrm{~min}$ & 15 & $66(3.1)$ & \\
\hline & $<20 \min$ & 65 & $72(1.9)$ & 0.06 \\
\hline & $>20 \mathrm{~min}$ & 35 & $66(2.5)$ & \\
\hline 10. Explanatory web & None & 14 & $68(3.8)$ & 0.67 \\
\hline pages read? & Up to a few pages & 42 & $69(2.3)$ & \\
\hline & All pages & 44 & $72(2.4)$ & \\
\hline & Less than all pages & 56 & $69(1.9)$ & 0.37 \\
\hline & All pages & 44 & $72(2.4)$ & \\
\hline 11. Navigate explanatory & In order presented & 66 & $70(2.2)$ & 0.66 \\
\hline pages? & Back and forth & 34 & $72(2.4)$ & \\
\hline 12. Time spent on entire & $<30 \min$ & 14 & $70(2.9)$ & 0.51 \\
\hline activity & $30 \mathrm{~min}$ to $1 \mathrm{~h}$ & 44 & $71(2.6)$ & \\
\hline & $1-2 \mathrm{~h}$ & 34 & $70(2.4)$ & \\
\hline & $>2 \mathrm{~h}$ & 8 & $62(5.8)$ & \\
\hline & $<2 \mathrm{~h}$ & 92 & $71(1.6)$ & 0.13 \\
\hline & $>2 \mathrm{~h}$ & 8 & $62(5.8)$ & \\
\hline 13. Try ring anomalies? & Yes & 24 & $64(3.7)$ & 0.04 \\
\hline & No & 76 & $72(1.6)$ & \\
\hline 14. Sensitivity-complacency? & Yes & 34 & $71(3.0)$ & 0.71 \\
\hline & No & 66 & $70(1.8)$ & \\
\hline 15. No. of rings in sample? & Yes & 50 & $66(2.3)$ & 0.006 \\
\hline & No & 50 & $74(1.8)$ & \\
\hline 16. Succeed in crossdating? & Yes & 93 & $70(1.6)$ & 0.43 \\
\hline & No & 7 & $66(5.7)$ & \\
\hline 17. Bog down in any way? & Yes & 34 & $66(2.9)$ & 0.08 \\
\hline & No & 66 & $72(1.7)$ & \\
\hline
\end{tabular}

\section{RESULTS}

\section{Crossdating Applet Package}

The average score on the comprehension test was 70\% (SE $=1.5, n=88$ ), with a low of $36 \%$ (one case) and a high of $93 \%$ (six cases). These scores represent fairly good comprehension of a new, difficult skill and its underlying concepts.

Survey Student Background. The modal class level of the respondents was juniors with also a large percentage of sophomores (Table 1, Question 1). Average test scores did not differ significantly by student class when each group was kept separate. When the students were divided into lower classmen (freshmen and sophomores) vs. upper classmen (juniors and seniors), the average group scores were still nearly identical. However, when the groups were combined into senior vs. junior or below, the older students scored significantly higher than the younger students. This last result contradicts other, more general research that has shown no significant difference between college seniors and freshmen in the ability to learn new concepts (Pascarella and Terezini, 1991).

Most respondents were nonscience majors, and only a few of them had any previous familiarity with crossdating and skeleton plotting (Table 1, Questions 2 and 3). There was no significant difference in test scores related to these characteristics.

One-third of the respondents had prior experience generally in computer-based activities (Table 1, Question 4), but there was no significant difference in test scores due to computer experience. The ultimate goal of web-based teaching modules and packages is not necessarily to be skilled at doing them, but rather to learn the topic that they cover. General computer literacy and comfort was probably helpful in mastering web-based crossdating, but inexperience with computer-based activities was not a detriment.

Styles of Executing the Applet. The respondents were split evenly between whether or not they resized the tree-ring sample or the graph paper of the applet (Table 1, Questions 5 and 6). Experienced crossdaters resize both objects - both virtually and in reality - because it is often necessary to zoom in on a tree-ring sample to see very narrow rings or out away from the graph paper to see longer patterns of marks. However, it is interesting that the applet's flexibility need not be fully exploited for it to be effective, because resizing objects did not affect test scores.

Most respondents needed to erase marks from their skeleton plots (Table 1, Question 7), which is not surprising; beginners and experienced crossdaters put marks on the wrong graph lines, change their minds on the length of marks, or both. Test scores did not differ significantly due to this feature.

Most respondents found it fairly to very easy to move the sample or graph papers, whereas $13 \%$ found this to be somewhat to very difficult (Table 1, Question 8). Moving the objects across the screen is imperative to succeeding with the applet, because the objects are too long to avoid extending off the edges of computer screens. Accordingly, there was a clear progression from high test scores by those who moved objects easily, to low test scores by those who found this to be difficult. Test scores differed significantly when analyzing the four groups and when analyzing two merged groups (easy to move vs. difficult to move). When using this web-based tool 
to teach crossdating, it is critical to stress the importance of learning how to move objects across the screen.

Most respondents needed less than 20 min to make their skeleton plot and match it with the master, while some took more than $40 \mathrm{~min}$ (Table 1, Question 9). It is reasonable for beginners to take anywhere from 5 to $20 \mathrm{~min}$ compared with the hours it can take to teach crossdating to large groups of students using real wood samples and graph strips. Test scores showed a trend-high scores for those who skeleton-plotted quickly and low scores for those who took more time. When grouped into less than $20 \mathrm{~min}$ vs. more than $20 \mathrm{~min}$, the quicker students did significantly better. This is an example of catching on quickly and doing well vs. struggling at length and still not doing as well.

Most respondents completed the entire activity, including writing the one-page summary, in less than $2 \mathrm{~h}$, with some taking less than $30 \mathrm{~min}$ (Table 1, Question 12). When grouped into less than $2 \mathrm{~h}$ vs. more than $2 \mathrm{~h}$, the quicker group scored better on the test. The difference between the average test scores technically was not significant, but that may have been due in part to the low sample size of the slower group. This appears to be another example of users comprehending concepts quickly and doing well vs. taking more time than was intended and still not doing well.

Styles of Navigating the Entire Package. Fourteen percent of the respondents did not read any of the explanatory web pages leading up to trying for themselves to crossdate (Table 1, Question 10). Respondents who read the pages were equally split between reading a few of the pages vs. reading all pages. Test scores did not differ significantly between these groups, either when analyzed as the three original groups or as two merged groups.

Two-thirds of the respondents who read at least a few pages did so in the sequential order given in the package, while the other third went back and forth between pages in no particular order (Table 1, Question 11). Test scores between these two groups were nearly identical. It is encouraging that the package serves equally well for students, regardless of their preference for learning sequentially or nonlinearly (Scherly et al., 2000). In general, flexible accommodation of various learning styles has been noted for hypermedia teaching tools (Hill et al., 1998).

Going beyond the Assignment. The official assignment included crossdating one tree-ring sample under the default settings; experimenting with more difficult samples was optional. Most respondents did not try ring anomalies or a complacent sample, but half tried changing the number of rings of the sample (Table 1, Questions 13, 14, and 15). Test scores did not differ significantly due to experimenting with sensitivity or complacency, but respondents who experimented with ring anomalies and/or with changing the number of rings curiously scored lower than those who did not bother with either of these features. Perhaps going on to more difficult concepts, without the aid of formal instruction on those concepts, confused some students on the basic concepts. It might be wise to invite eager students to an optional lab session to discuss these extra concepts before they try harder settings for themselves.

Successful Crossdating. Almost all respondents succeeded at crossdating at least one tree-ring sample (Table 1, Question 16). Successful respondents scored better on the test than those who did not crossdate a tree-ring sample, but the difference was not significant, perhaps due to the low sample size of the group that did not succeed. It was gratifying to see such high success at crossdating and comprehension of the underlying concepts amongst undergraduate nonscience majors who had no prior awareness of crossdating.

Instructional Lessons Learned. One-third of the respondents bogged down, that is, reached a point of frustration where they quit for awhile during the assignment (Table 1, Question 17). Bogging down can seriously counteract positive advantages of a technological learning tool, as it takes only minor technical glitches before students become disillusioned with technology (Shaw and Marlow, 1999). Comments about what happened can be summarized as follows:

- Accidentally made marks on the master chronology skeleton plot and became confused. This refers to the fact that the crossdating applet allowed users to insert and remove marks on the skeleton plot of the master chronology. This feature complicated learning when users accidentally changed the master chronology skeleton plot without realizing how to recover the original. In response to this comment, this feature has been removed from the applet, illustrating the ease and speed with which web-based teaching tools can be modified or updated.

- Found it hard to print the final crossdating demonstration. This reflects the fact that Java-language applets cannot be printed directly from web browsers. To document having done the activity, students were told of an alternative way of printing their work, that is, to capture an image of the screen and then paste the image into any standard word processing document (an image such as Fig. 1). The majority of students did not struggle with this approach, but several students had problems with this and spent too much time trying to overcome this step. This was unfortunate; printing the crossdating results was not a learning objective per se of the activity.

- Did not understand how to get started until seeing an inclass demonstration. This reflects the need to demonstrate computer activities in class, regardless of how easy they may appear to the professor. It is helpful for students to see something like the crossdating applet done at least once before trying it for themselves. I had demonstrated the applet in class before they tried it, but multiple demonstrations may be better.

What the Students Learned. Based on the crossdating test (Table 2), the students comprehended several important points about dendrochronological crossdating, including the following:

- Skeleton plot marks differ for narrow, average, and wide rings (Questions 1, 12-14).

- The potential existence of ring anomalies makes crossdating better than merely ring counting (Question 2).

- Skeleton plots done by different people need not be identical for crossdating to work (Question 3).

- Differing growth rates of trees are equalized by skeleton plots (Question 4).

- Specimens from living or dead trees are equally crossdateable (Question 5).

- Master chronologies are made up of other dated specimens (Question 6).

J. Nat. Resour. Life Sci. Educ., Vol. 31, 2002

127 
Table 2. Questions and results for crossdating test. Underlined answer is correct.

\begin{tabular}{|c|c|c|}
\hline Question & Answer & $\begin{array}{l}\% \text { of Re- } \\
\text { spondents }\end{array}$ \\
\hline \multirow{4}{*}{$\begin{array}{l}\text { 1. When making skeleton plots, it is helpful to } \\
\text { make a mark on every line of the graph paper. } \\
\text { 2. Simple ring counting might not be sufficient } \\
\text { for dating tree rings because of missing and/ } \\
\text { or false rings. }\end{array}$} & True & 7 \\
\hline & False & 93 \\
\hline & True & 88 \\
\hline & False & 12 \\
\hline \multirow{2}{*}{$\begin{array}{l}\text { 3. Skeleton plots made by different people for } \\
\text { the same tree-ring sample must be identical } \\
\text { for crossdating to work. }\end{array}$} & True & 25 \\
\hline & False & 75 \\
\hline \multirow{2}{*}{$\begin{array}{l}\text { 4. Dendrochronologists often prefer to compare } \\
\text { skeleton plots on graph paper rather than } \\
\text { samples of actual wood. }\end{array}$} & $\underline{\text { True }}$ & 84 \\
\hline & $\overline{\text { False }}$ & 16 \\
\hline \multirow{2}{*}{$\begin{array}{l}\text { 5. To be crossdated, tree-ring samples must } \\
\text { come from currently living trees. }\end{array}$} & True & 5 \\
\hline & False & 95 \\
\hline \multirow{2}{*}{$\begin{array}{l}\text { 6. A master tree-ring chronology is created from } \\
\text { other, previously crossdated trees. }\end{array}$} & $\overline{\text { True }}$ & 92 \\
\hline & $\overline{\text { False }}$ & 8 \\
\hline \multirow{2}{*}{$\begin{array}{l}\text { 7. Crossdating by skeleton plotting can be } \\
\text { used to accurately date virtually any and all } \\
\text { tree-ring samples. }\end{array}$} & True & 65 \\
\hline & False & 35 \\
\hline \multirow{2}{*}{$\begin{array}{l}\text { 8. When crossdating a relatively complacent } \\
\text { sample, it should have lots of rings. }\end{array}$} & True & 36 \\
\hline & False & 64 \\
\hline \multirow[t]{3}{*}{ 9. Another name for crossdating is: } & radiometric dating & 33 \\
\hline & pattern matching & 52 \\
\hline & superposition & 15 \\
\hline \multirow{3}{*}{$\begin{array}{l}\text { 10. The variability of tree ring widths in a } \\
\text { complacent tree-ring sample is: }\end{array}$} & above average & 15 \\
\hline & average & 57 \\
\hline & below average & 28 \\
\hline \multirow{3}{*}{$\begin{array}{l}\text { 11. The variability of tree ring widths in a } \\
\text { sensitive tree-ring sample is: }\end{array}$} & above average & 57 \\
\hline & average & 16 \\
\hline & below average & 26 \\
\hline \multirow{3}{*}{$\begin{array}{l}\text { 12. When crossdating a sample, it is best to } \\
\text { focus on the tree rings that are: }\end{array}$} & narrow & 87 \\
\hline & of average width & 7 \\
\hline & wide & 6 \\
\hline \multirow{3}{*}{$\begin{array}{l}\text { 13. The longest marks on the skeleton plot } \\
\text { represent the tree rings that are: }\end{array}$} & the narrowest & 86 \\
\hline & the most typical & 7 \\
\hline & the widest & 7 \\
\hline \multirow{3}{*}{$\begin{array}{l}\text { 14. Average rings merit what kind of mark } \\
\text { on the skeleton plot: }\end{array}$} & average marks & 20 \\
\hline & b marks & 7 \\
\hline & no marks at all & 73 \\
\hline
\end{tabular}

The concept of dendrochronological sensitivity vs. complacency was not grasped well (Questions 8, 10, and 11). Although this concept is not overly complicated, perhaps more instructional emphasis on it is warranted. Only one-third of the students experimented with changing the sensitivity-complacency setting; this could be because learning this concept was not required to fulfill the assignment.

Many respondents missed the point that crossdating is nothing more than pattern matching (Question 9), that is, matching ring-width patterns across tree-ring samples or chronologies. This concept was stated in the explanatory pages, but some students may have been drawn to the question's other choices, both of which were familiar terms covered in previous lectures.

The fact that $65 \%$ of the respondents believed crossdating can date virtually all tree-ring samples (Question 7) was surprising. Some tree-ring samples cannot be crossdated (e.g., those with ring growth that is very complacent, too short, and/or afflicted with many ring anomalies), and this was admitted or implied in the explanatory pages. Perhaps the ease of succeeding at crossdating a sample of the applet lulled students into thinking that crossdating is always so easy. Anecdotal evidence has indicated that many beginners prefer to continue playing with the applet instead of moving on to crossdating real wood samples, which can be more difficult than the applet. The reality of dendrochronological crossdating should be emphasized so that students do not form or cling to unwarranted expectations.

\section{Southwest Forest Fire Management Module}

The average pretest score was $53 \%(\mathrm{SE}=1.5, n=108)$ with a maximum score of $88 \%$, indicating only a minimal understanding of the issues of forest fire management in the Southwest before doing the web-based module and essay assignment. The average posttest score was $74 \%(\mathrm{SE}=1.8, n=95)$, with a maximum score of $100 \%$ by two respondents. This was a highly significant improvement from pretest to posttest, indicating substantial learning about this complex issue due to the Southwest forest fire management module.

What the Students Learned. Based on the pretests and posttests (Table 3 ), the students comprehended several points about forest fire management in the Southwest, including the following:

- Past fire regimes can be reconstructed by analyzing fire scars using dendrochronological crossdating (Questions 4 and 11).

- Modern fire regimes differ from prehistoric regimes in terms of fire frequency and intensity and area burned (Questions 3,6 , and 8).

- Stand composition and fuel loading of ponderosa pine forests have also changed through time (Questions 5 and 12).

- Crown fires differ from low-intensity ground fires in their effects on forests (Questions 4 and 14).

- Changes in fire regimes have occurred due to multiple factors (Question 13).

- Fires may be started on purpose as a management tool (Questions 9 and 10).

Instructional Lessons Learned. Other concepts were not comprehended well, even after doing the forest fire module. Question 1 may have tricked students into not reading all the choices; prescribed burning was certainly a correct choice, but the other choices were also correct, making all of the above the final answer. The role of grasses in fire regimes (Question 2 ) is subtle and depends on other factors such as total fuel loading and fuel moisture content (Swetnam and Betancourt, 1990). Also, it is true that major advances in fire suppression technology took place after World War II (Sanderson, 1974) (Question 7), but most southwestern ponderosa pine fire regimes had already begun changing by the late 1800 s (Swetnam and Baisan, 1996).

The web-based module does not cover fire regimes for forest types other than ponderosa pine (Question 15), largely because other southwestern forest types do not have abundant trees with multiple fire scars from which to reconstruct past fire regimes (Wright and Bailey, 1982). This point was mentioned briefly in the lecture introduction to the web-based module, but perhaps more emphasis is merited for other types of forest fire regimes.

Conversely, the module does contain master fire chronologies that show no change in their fire regimes throughout the 20th century (Question 16). The module also links to a reference explaining why these sites have not changed: The Hidden Kipuka and Mesita Blanca sites of El Malpais National Monument were out of reach from grazing and fire control efforts because of large, rough lava flows that surround the sites (Grissino-Mayer and Swetnam, 1997). However, all of the other master fire chronologies included in the module 
Table 3. Questions and results for pretests and posttests on southwestern forest fire management. Underlined answer is correct.

\begin{tabular}{|c|c|c|c|c|c|c|c|c|c|}
\hline \multirow[b]{2}{*}{ Question } & \multirow[b]{2}{*}{ Answer } & \multicolumn{2}{|c|}{$\begin{array}{l}\% \text { of Re- } \\
\text { spondents }\end{array}$} & \multirow[b]{2}{*}{$\begin{array}{l}\text { Differ- } \\
\text { ence }\end{array}$} & \multirow[b]{2}{*}{ Question } & \multirow[b]{2}{*}{ Answer } & \multicolumn{2}{|c|}{$\begin{array}{l}\% \text { of Re- } \\
\text { spondents }\end{array}$} & \multirow[b]{2}{*}{$\begin{array}{l}\text { Differ- } \\
\text { ence }\end{array}$} \\
\hline & & $\begin{array}{l}\text { Pre } \\
\text { test }\end{array}$ & $\begin{array}{c}\text { Post } \\
\text { test }\end{array}$ & & & & $\begin{array}{l}\text { Pre } \\
\text { test }\end{array}$ & $\begin{array}{l}\text { Post } \\
\text { test }\end{array}$ & \\
\hline \multirow{11}{*}{$\begin{array}{l}\text { 1. Restoring wild land } \\
\text { fire to its more natural } \\
\text { role in the southwest } \\
\text { may involve: } \\
\text { 2. Grasses help spread } \\
\text { ground-level fires, } \\
\text { thereby: }\end{array}$} & •prescribed burning & 30 & 43 & \multirow{9}{*}{-6} & \multirow{10}{*}{$\begin{array}{l}\text { 8. The trend in total } \\
\text { acreage of forest land } \\
\text { burned per year in the } \\
\text { southwest since the } \\
\text { mid } 1900 \text { s has: } \\
\text { 9. Controlled burning } \\
\text { is affected by: }\end{array}$} & • been upward & 46 & 77 & \multirow[t]{9}{*}{+31} \\
\hline & - mechanical fuel reduction & 5 & 4 & & & •been downward & 35 & 13 & \\
\hline & - active fire suppression & 6 & 0 & & & \multirow[t]{2}{*}{-stayed about the same } & \multirow[t]{3}{*}{19} & \multirow[t]{2}{*}{10} & \\
\hline & - all of the above & 59 & 53 & & & & & & \\
\hline & $\begin{array}{l}\text { - increasing the frequency of } \\
\text { large, severe fires }\end{array}$ & 40 & 35 & & & \multirow{3}{*}{$\begin{array}{l}\text { - having to wait for certain } \\
\text { weather conditions } \\
\text { - the risk of the fire burning }\end{array}$} & & & \\
\hline & - causing extinction of many & 4 & 6 & & & & 10 & 3 & \\
\hline & forest species & & & & & & \multirow[t]{2}{*}{6} & \multirow[t]{2}{*}{3} & \\
\hline & •causing soil destruction so that & 12 & 1 & & & out of control & & & \\
\hline & forests may not regrow for centuries & & & & & - air quality impacts & 2 & 0 & \\
\hline & - increasing the frequency of small. & 44 & 58 & \multirow[t]{2}{*}{+14} & & - all of the above & 82 & 94 & +12 \\
\hline & low-intensity fires & & & & 10. What is the word used & -prescribed & 79 & 95 & +16 \\
\hline 3. Compared with the & - $\underline{\text { ess frequent but more severe fires }}$ & 32 & 70 & +38 & by forest managers to & - dictated & 11 & 3 & \\
\hline southwest's natural & - more frequent and more severe & 19 & 21 & & describe a fire that has & - accidental & 6 & 1 & \\
\hline fire regime, the & fires & & & & been set by forest & •natural & 4 & 1 & \\
\hline modern fire regime & - about the same amount of fires & 16 & 3 & & rangers in the hopes of & & & & \\
\hline tends to include: & •less frequent and smaller fires & 14 & 0 & & avoiding a bigger fire & & & & \\
\hline & - more frequent but smaller fires & 19 & 6 & & later? & & & & \\
\hline 4. The fact that a tree has & $\cdot$ very severe & 31 & 16 & & 11. How do dendrochro- & - They look for narrow rings in & 13 & 4 & \\
\hline recorded several scar & •crown fires & 14 & 9 & & nologists determine & young trees & & & \\
\hline injuries from past fires & - $\underline{\text { light in severity }}$ & 49 & 74 & +25 & the fire regime for an & - They compare fire scars on & 62 & 87 & +25 \\
\hline indicates that those & •human ignited & 6 & 1 & & area during the years & burned trees & & & \\
\hline $\begin{array}{l}\text { particular fires were } \\
\text { probably: }\end{array}$ & & & & & $\begin{array}{l}\text { before historic docu- } \\
\text { ments were common- }\end{array}$ & $\begin{array}{l}\text { - They use tree-ring cores from } \\
\text { aspen }\end{array}$ & 7 & 1 & \\
\hline $\begin{array}{l}\text { 5. Fuel loading can best } \\
\text { be described as: }\end{array}$ & $\begin{array}{l}\text { - when visitors load collected } \\
\text { fuelwood from the forest into }\end{array}$ & 9 & 1 & & place? & $\begin{array}{l}\text { - They use tree rings to date the } \\
\text { layer of ash in a soil }\end{array}$ & 18 & 8 & \\
\hline & their vehicle for home use & & & & 12. Compared with the & - denser, with smaller trees & 16 & 64 & +48 \\
\hline & •when a forest ranger pours & 29 & 6 & & ponderosa pine forests & - denser, with larger trees & 18 & 16 & \\
\hline & gasoline on an area to initiate & & & & of the past, south- & •thinner, with more grasses & 47 & 14 & \\
\hline & a prescribed burn & & & & western ponderosa & - thinner, with larger trees & 10 & 5 & \\
\hline & - leaves, dead wood, and even & 58 & 93 & +25 & pine forests today are: & - the same as they ever were & 9 & 1 & \\
\hline & $\begin{array}{l}\text { living trees in the forest that } \\
\text { may burn in a fire }\end{array}$ & & & & $\begin{array}{l}\text { 13. What factor below has } \\
\text { the LEAST effect on }\end{array}$ & $\begin{array}{l}\text { - grazing of domestic animals } \\
\text { in forests }\end{array}$ & 18 & 9 & \\
\hline & -when the pine cones crackle and & 4 & 0 & & the Southwest's & - suppression of fires by people & 8 & 1 & \\
\hline & explode during a big fire & & & & modern fire regime? & • rainfall patterns & 14 & 5 & \\
\hline 6. The southwest's & - humans have been suppressing & 49 & 79 & +30 & & - arrival of snowbirds & 58 & 83 & +25 \\
\hline modern fire regimes & fires for the past hundred years & & & & & • fuel loading & 2 & 2 & \\
\hline differ from the natural & or so & & & & 14. A crown fire can best & - circles the top of a mountain & 35 & 8 & \\
\hline fire regimes in part & $\cdot \overline{\text { lightning strikes are more power- }}$ & 9 & 5 & & be described as a fire & - reaches the tops of the trees & 25 & 72 & +47 \\
\hline because: & ful now, leading to larger fires & & & & that: & -reaches the top of a mountain & 20 & 3 & \\
\hline & - grazing by cattle in forests causes & 20 & 12 & & & - circles the tops of the trees & 20 & 17 & \\
\hline & an increase in grass production that & & & & 15. Natural fire regimes & - True & 79 & 66 & -13 \\
\hline & carries the fires greater distances & & & & of southwestern & $\overline{\text { False }}$ & 21 & 34 & \\
\hline & $\begin{array}{l}\text { - trees are more widely spaced now } \\
\text { than they were in the past }\end{array}$ & 22 & 4 & & $\begin{array}{l}\text { ponderosa pine forests } \\
\text { differ from those of }\end{array}$ & & & & \\
\hline 7. Forest fire regimes of & •World War II & 17 & 22 & & southwestern & & & & \\
\hline the southwest began & • initial Spanish contact & 18 & 10 & & spruce-fir forests. & & & & \\
\hline changing soon after: & - cattle and sheep grazing became & 61 & 65 & +4 & 16. Without exception, & •True & 36 & 47 & \\
\hline & $\begin{array}{l}\text { large-scale operations in the } \\
\text { Southwest }\end{array}$ & & & & $\begin{array}{l}\text { every fire history site } \\
\text { in the southwest shows }\end{array}$ & • $\underline{\text { False }}$ & 64 & 53 & -11 \\
\hline & $\begin{array}{l}\text { - Mexico won independence } \\
\text { from Spain }\end{array}$ & 4 & 3 & & $\begin{array}{l}\text { a sharp change in fire } \\
\text { frequency at the same ti }\end{array}$ & ime. & & & \\
\hline
\end{tabular}

show fire regime changes at about the same time, and many students failed to notice the exception of the El Malpais sites.

\section{CONCLUSIONS}

The web-based tools described here for teaching dendrochronology were successful. The crossdating applet package resulted in substantial comprehension of what was a new concept for the students of the course. Before the existence of the interactive applet and accompanying explanatory pages, teaching crossdating was limited to courses with only a few students, to using relatively static demonstrations with transparencies, and to assigning paper exercises without vivid explanatory packets. By comparison, the crossdating applet is a marked improvement.

The southwestern forest fire management module significantly improved understanding of that complex environmen- tal issue. Without the module, students would have had to spend much more time searching for primary material and fire history data, and their thinking about the issues and their writing might have suffered. Without the module, other course assignments might have been skipped to be able to devote extra time to the fire management essay. By comparison, the selfcontained module is attractive as a single source of pertinent information.

Changes to the crossdating applet have already been made based on student comments, and the fire management module is updated every year to include more information, usually about the latest fire season. Fortunately, it is easy to make such changes because these teaching tools are located on the web (Pelton and Pelton, 1998). The success of these tools and the attractiveness of the web as a teaching medium justify additional modules on yet other environmental issues. 
I welcome other educators to use these web-based tools. I am also interested in continuing a formal evaluation of these tools using student respondents from different institutions. Please write to inquire about the current URLs of the tools and to discuss the evaluation surveys and tests.

\section{ACKNOWLEDGMENTS}

I thank Elena Berman, Jeffrey Dean, David Grow, Malcolm Hughes, Melanie Lenart, Sharon McKenzie Stevens, and Thomas Swetnam for their assistance. This project was funded in part with a New Learning Environments grant from the University of Arizona.

\section{REFERENCES}

Babbitt, B. 1995. Return fire to its place in the west. Fire Management Notes 55(4):6-8.

Carr-Chellman, A., and P. Duchastel. 2000. The ideal online course. Br. J. Educ. Technol. 31:229-241.

Collis, B. 1998. New didactics for university instruction: Why and how? Computers \& Education 31:373-393.

Czerniak, C.M., A.T. Lumpe, J.J. Haney, and J. Beck. 1999. Teachers' beliefs about using educational technology in the science classroom. International Journal of Educational Technology 1(2). Available online at http://www.outreach.uiuc.edu/ijet/v1n2/czerniak/index.html (accessed 24 Sept. 2002; verified 9 Oct. 2002). Univ. of Illinois, Urbana, IL.

Dean, J.S. 1969. Dendrochronology and archaeological analysis: A possible Ute example from southwestern Colorado. Southwestern Lore 35:29-41.

Farber, E. 1999. College libraries and the teaching/learning process: A 25year reflection. Journal of Academic Librarianship 25:171-177.

Fritts, H.C. 1976. Tree rings and climate. Academic Press, New York

Fritts, H.C. 1991. Reconstructing large-scale climatic patterns from tree-ring data. Univ. of Arizona Press, Tucson.

Fritts, H.C., and T.W. Swetnam. 1989. Dendroecology: A tool for evaluating variations in past and present forest environments. Adv. Ecol. Res. 19:111-188.

Grissino-Mayer, H.D., and T.W. Swetnam. 1997. Multi-century history of wildfire in the ponderosa pine forests of El Malpais. p. 163-171. In K Mabery (ed.) Natural history of El Malpais National Monument. Bull. 156. New Mexico Bureau of Mines and Mineral Resources, Socorro NM.

Hill, M., J.D. Bailey, and P.A.S. Reed. 1998. Hypermedia systems for improving knowledge, understanding and skills in engineering degree courses. Computers \& Education 31:69-88.

Jacoby, G.C., P.R. Sheppard, and K.E. Sieh. 1988. Irregular recurrence of large earthquakes along the San Andreas Fault: Evidence from trees. Science (Washington, DC) 241:196-199.
Jozsa, L.A. 1985. Contribution of tree-ring dating and wood structure analysis to the forensic sciences. Can. Soc. Forensic Sci. J. 18:200-210.

Leavitt, S.W., W.E. Wright, and A. Long. 1998. ENSO signal in $\delta^{13} \mathrm{C}$ of preand post-false latewood of ponderosa pine tree rings in southeastern Arizona. p. 37-44. In R. Wilson and V.L. Tharp (ed.) Proc. of the 14th Annual Pacific Climate (PACLIM) Workshop, Asilomar, CA. 6-9 Apr. 1997. Tech. Rep. 57. California Dep. of Water Resources, Interagency Ecological Program for the Sacramento-San Joaquin Estuary, Sacramento, CA.

Lewis, T.E. (ed.). 1995. Tree rings as indicators of ecosystem health. CRC Press, Boca Raton, FL.

Pascarella, E.T., and P.T. Terezini. 1991. How college affects students: Findings and insights from twenty years of research. Jossey-Bass Publ., San Francisco, CA.

Pelton, L.F., and T.W. Pelton. 1998. Using WWW, usenets, and e-mail to manage a mathematics pre-service technology course. Computers in the Schools 14(3/4):79-93.

Sanderson, J.E. 1974. The role of fire suppression in fire management. p 19-31. In Proc. of the 14th Tall Timbers Fire Ecology Conf., Missoula, MT. 8-10 Oct. 1974. Tall Timbers Research Stn., Tallahasee, FL.

Scherly, D., L. Roux, and P. Dillenbourg. 2000. Evaluation of hypertext in an activity learning environment. Journal of Computer Assisted Learning 16:125-136.

Shaw, G., and N. Marlow. 1999. The role of student learning styles, gender, attitudes and perceptions on information and communication technology assisted learning. Computers \& Education 33:223-234.

Sokal, R.R., and F.J. Rohlf. 1981. Biometry. W.H. Freeman and Co., San Francisco, CA.

Surry, D.W., and S.M. Land. 2000. Strategies for motivating higher education faculty to use technology. Innovations in Education and Training International 37:145-153.

Suskie, L.A. 1996. Questionnaire survey research: What works. Rep. No. 6. Assoc. for Institutional Res., Resources for Institutional Res., Tallahassee, FL.

Swetnam, T.W., and C.H. Baisan. 1996. Historical fire regime patterns in the southwestern United States since AD 1700. p. 11-32. In C. Allen (ed.) Fire Effects in Southwestern Forests, Proc. of the Second La Mesa Fire Symp., Los Alamos, NM. 29-31 Mar. 1994. USDA Forest Service General Tech. Rep. RM-GTR-286. USDA-Forest Service, Washington, DC.

Swetnam, T.W., and J.L. Betancourt. 1990. Fire: Southern oscillation relations in the southwestern United States. Science (Washington, DC) 249:1017-1020.

University of Arizona. 2002. University of Arizona academic catalogs [Online]. [1 p.] Available at http://catalog.arizona.edu/allcats.html (accessed 24 Sept. 2002; verified 9 Oct. 2002). Univ. of Arizona, Tucson, AZ.

Whittingham, C.D., and L.M. Campbell. 1999. Task-oriented learning on the web. Innovations in Education and Training International 36:26-33.

Wright, H.A., and A.W. Bailey. 1982. Fire ecology, United States and southern Canada. Wiley, New York.

Young, J. 1998. Computers and teaching: Evolution of a cyberclass. Political Science and Politics 31:568-572. 